Ethology / Éthologie

\title{
Few, small, and male: Multiple effects of reduced nest space on the offspring of the solitary wasp, Euodynerus (Pareuodynerus) posticus (Hymenoptera: Vespidae)
}

\author{
Carlo Polidori ${ }^{\mathrm{a}, *}$, Roberto Boesi ${ }^{\mathrm{a}}$, Walter Borsato ${ }^{\mathrm{b}}$ \\ ${ }^{a}$ Dipartimento di Biologia, Sezione di Zoologia e Citologia, Università degli Studi di Milano, via Celoria, 26, 20133 Milano, Italy \\ b via Valpantena 20/c, 37034 Quinto di Valpantena, Italy
}

\section{A R T I C L E I N F O}

\section{Article history:}

Received 7 July 2010

Accepted after revision 10 November 2010

Available online 24 December 2010

\section{Keywords:}

Nest size

Biased sex-ratio

Body size

Trap-nesting

Eumeninae

\begin{abstract}
A B S T R A C T
The size of the preexisting wood cavities used as nests by aculeate Hymenoptera is expected to have consequences on fitness parameters such as offspring number and size. We evaluated the consequences of using small and large (three-times more voluminous) trap-nests by the solitary wasp, Euodynerus (Pareuodynerus) posticus (Herrich-Schaeffer). Following life-history and sex allocation theories, a number of non-mutually exclusive hypotheses were formulated: i.e. small nests either produce smaller or fewer offspring and/or more males, the cheaper sex. Wasps built about $28 \%$ more, but shorter brood cells in large nests, although their volume was still much higher in large nests. Adult males had smaller body size in small nests, but female size did not differ between large and small nests, possibly as an adaptive response against the future higher foraging costs of sizereduced females. Sex-ratio was often biased towards males in small nests. Mortality did not differ between large and small nests. We conclude that $E$. (P.) posticus females would benefit from using larger nests, but that the sex-ratio would be probably overall unbalanced if females would not use also smaller, male-oriented tunnels.
\end{abstract}

(C) 2010 Académie des sciences. Published by Elsevier Masson SAS. All rights reserved.

\section{Introduction}

Many species of solitary bees and wasps (Hymenoptera: Apoidea and Vespoidea) nest in preexisting cavities dug in wood by other animals [1-3]. Together with the availability of adequate habitats and landscape characteristics [3-7], the availability of suitable cavities for nest construction, as those provided for example by woodboring beetles, is known to be a limiting factor for these insects [8-10].

The optimal use of the nesting resource is thus crucial for wood-nesting bees and wasps in order to increase their fitness, and these species should behave in a way that maximizes their fitness in poorer conditions. In fact,

\footnotetext{
* Corresponding author.

E-mail address: carlo.polidori@unimi.it (C. Polidori).
}

life-history theory predicts that resource availability shapes life-history-traits and even drives the evolution of organisms [11]. For example, theory predicts that parents respond to resource limitation (including nesting substrate) moving the sex-ratio towards the smallest, and thus cheapest, sex, and it was reported in a number of trapnesting Hymenoptera species [1,12-19]. Another problem faced by females that nest in small spaces is the trade-off between size and number of offspring. Theory predicts that parents should attempt to adjust offspring number rather than size to maximize fitness per unit invested [20]; that is, fewer but large individuals should be produced in poor conditions, and this was also reported for Hymenoptera when food resource was experimentally reduced [21], or when females were exposed to naturally poor or variable food availability [22,23]. However, because tunnels in wood cannot be expanded, in the case of nesting space limitations, adjusting the number of offspring and 
favouring their size may be more difficult and, as a matter of fact, many studies on trap-nesting Hymenoptera reported both offspring size and number to be reduced in small nests, contrasting partially with the general hypothesis reported above $[1,13-16,18,19]$. In this last situation, nesting females, producing smaller offspring, may affect negatively the following adult generation, due to the general positive correlation between size and components of fitness in aculeate Hymenoptera (e.g. fecundity: [24,25]; load-lifting capacity: [26,27]; intraspecific contests: $[28,29])$.

Small nests may also suffer an additional higher risk of brood mortality, as a number of studies on trap-nesting Hymenoptera showed [14,30,31]. Nesting females could balance this risk by providing more defensive structures to the nests, such as a large vestibular cell (see definitions in Materials and methods), which was shown, to some extent, to reduce total mortality in some wood-nesting species $[32,33]$, although not the rate of parasitism by parasitoids [32-35].

We carried out a study on the wood-nesting, solitary wasp Euodynerus (Pareuodynerus) posticus (HerrichSchaeffer)(Vespidae: Eumeninae) to test these predictions, offering the nest-searching females both large and small tunnels in which to nest. Because many species of aculeate Hymenoptera easily accept artificially prepared trap-nests such as burrows drilled in wood blocks [1-3], these insects are models to test hypotheses related to life-history, optimal foraging and optimal allocation theories [15-17]. In particular, according to such theories, we hypothesized that small nests produce smaller or fewer offspring and/or more males, the cheaper sex. In addition, we evaluated mortality rate in both types of nests. Despite the relationships between nest size, productivity, offspring size and sex-ratio were assessed for many bees and wasps (see above), a detailed analysis of nest structure and its relationship with components of the allocation behaviour was conducted only for a few species of Euodynerus (only three with an adequate sample size) $[1,24]$. We think that new data on a further, biologically unknown, species such as $E$. (P.) posticus may be of interest for future comparative analyses on the behaviour of such insects.

\section{Materials and methods}

\subsection{Study organisms}

The vespid subfamily Eumeninae includes about 3000 species worldwide and about 200 in Europe [36,37]. Females are, with few exceptions $[38,39]$, solitary insects and make their nests with mud and clay or leaves, dig them in the soil, or readily use wood borings and other preexisting tubular cavities $[1,40,41]$; mated females hunt for either Lepidoptera or Coleoptera larvae (rarely for both orders) to feed their offspring, which are reared one per cell in the nest $[1,12,41,42]$. When the wasp has collected enough food for one larva, it seals the brood cell and starts to work on a new one $[41,42]$. Differently from most bees and wasps, eumenine wasps lay the egg in the empty cell, before the provisions are added [41].

In eumenine wood-nesting wasps, the basic structure of the nest includes a number of brood cells (where eggs are laid and brood provisioned, BC), separated by mud partitions (MP); to the outermost of the nest, after completing and sealing the last brood cell, a vestibular cell (a cell not provisioned delimited by the mud partition of the last brood cell and the nest entrance, VC) may be present; nest is then closed with a mud partition at the entrance hole called closing plug (CP); in addition, brood cells may be separated by intercalary cells (non-provisioned cells, shorter than the brood cells) [1] (Fig. 1).

The genus Euodynerus comprises 44 species in the Paleartic Region, of which 12 belong to the subgenus Pareuodynerus [43]. Most species of the genus occupy preexisting cavities to nest, but soil-nesting was also reported [44]; females provision the immature offspring with Lepidoptera larvae $[1,45,46]$. Recent samplings suggest that $E$. (P.) posticus, our study species, may prefer as habitat the edge between inland grassland and forest, trails inside the forest and grasslands, at least in an area placed at about $150 \mathrm{~km}$ from our study site (see below) [47].

\subsection{Trap-nesting protocol and data collection}

Trap-nests were placed in a natural reserve in Northern Italy, named La Fagiana (Ticino Regional Park, Magenta, Italy: $\left.45^{\circ} 26^{\prime} 15^{\prime \prime} \mathrm{N}-8^{\circ} 49^{\prime} 47^{\prime \prime} \mathrm{E}\right)$. The site is characterized by a continental climate, with cold winters and hot summers. Nests were placed under the roof of a Park building, at 2$2.5 \mathrm{~m}$ above the soil.

A total of 196 trap-nests were grouped in four blocks of 50 units (one of 46 units) during early June of 2003. Trapnests were made using wood of Abies alba (according to [1]). The wood sticks $(2 \times 2 \mathrm{~cm}$ of square section and $10 \mathrm{~cm}$ in length) were drilled with a longitudinal hole to provide a suitable space where wasps could establish their nests. Hole diameters were of two sizes: $6 \mathrm{~mm}$ (corresponding to a tunnel length of $80 \mathrm{~mm}$ and a volume of $2.26 \mathrm{~cm}^{3}$ ) and $10 \mathrm{~mm}$ (corresponding to a tunnel length of $90 \mathrm{~mm}$ and a volume of $\left.7.06 \mathrm{~cm}^{3}\right)$. Both nest-hole diameters provided were considerably larger than the mean head width of

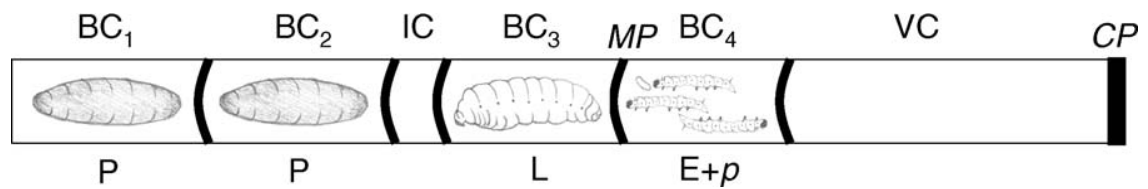

Fig. 1. The typical structure of a trap-nesting eumenine nest. Brood cells (BC) are built and provisioned from the bottom (left) to the entrance (right). Nonprovisioned intercalary cells (IC) typically are between two BCs. Each BC is sealed with a mud partition (MP), while the nest is sealed with a closing plug of mud $(C P)$. Prior to the $C P$, a non-provisioned vestibular cell $(\mathrm{VC})$ can be present. P: puparium, L: larva, E+p: egg + prey (here lepidopteran larvae). 
females (see below), so that females could comfortably enter both types of holes. A total of $966-\mathrm{mm}$ nests and 100 $10-\mathrm{mm}$ nests were placed. Within each block, equal numbers of $6-\mathrm{mm}$ nests and $10-\mathrm{mm}$ nests were located in a random position. At intervals of 2 weeks nest blocks were checked in order to assess the number of generations of the wasp.

All the trap-nests were collected in late September 2003, when the nesting period of the wasps was assumed, given the limited data available in literature on the phenology of eumenine wasps in the Mediterranean, to be finished [48]. At removal, the trap-nest holes may be either closed with mud (the sign of a completed nest) or open (the sign of an unused hole or an incomplete nest). A wasp would heavily risk leaving the nest open and abandoning it with provisions or larvae inside. Moreover, it is impossible (in absence of a closing plug) to determine if the nest was not completed because of an alternative wasp strategy (unlikely for the reason above) or because, e.g., it died during provisioning. Thus, we defined as completed nests only those that presented a closing plug (and thus independently from how much space was used by the wasps for, e.g. provisioning).

All nests were covered with net or adhesive tape, to avoid escapes from each trap, and they were then brought at the laboratory and located in a room at $15-20^{\circ} \mathrm{C}$

Table 1

Comparisons of different nest and wasp variables between small and large nests colonized by $E$. (P.) posticus. $t$ value refers to Student's $t$-test (* if AspinWelch was used due to non-homogeneity of variance), U refers to Mann-Whitney test and G refers to the likelihood-ratio G-test. Statistics are in bold if significant at $P<0.05$.

\begin{tabular}{|c|c|c|c|}
\hline Variable & 6-mm tunnel & 10-mm tunnel & Statistics \\
\hline Head width (mm) (general) & $\begin{array}{l}\text { Mean }=2.67 \pm 0.36, \text { median }=2.64 \\
\text { range }=1.90-3.56, n=85\end{array}$ & $\begin{array}{l}\text { Mean }=3.02 \pm 0.33, \text { median }=3.11 \\
\text { range }=2.23-3.66, n=112\end{array}$ & $t=-6.84, \mathrm{df}=195, \mathrm{P}<0.001$ \\
\hline Head width (mm) (females) & $\begin{array}{l}\text { Mean }=3.14 \pm 0.21, \text { median }=3.13 \\
\text { range }=2.75-3.56, n=21\end{array}$ & $\begin{array}{l}\text { Mean }=3.22 \pm 0.16, \text { median }=3.24 \\
\text { range }=2.79-3.65, n=68\end{array}$ & $t=-1.90, \mathrm{df}=87, P=0.059$ \\
\hline Head width (mm) (males) & $\begin{array}{l}\text { Mean }=2.51 \pm 0.24, \text { median }=2.53 \\
\text { range }=1.90-2.99, n=66\end{array}$ & $\begin{array}{l}\text { Mean }=2.68 \pm 0.26, \text { median }=2.74 \\
\text { range }=2.23-3.66, n=43\end{array}$ & $t=-3.31, d f=107, P=0.0012$ \\
\hline $\begin{array}{l}\text { Brood cell length (mm) } \\
\quad \text { (general) }\end{array}$ & $\begin{array}{l}\text { Mean }=17.03 \pm 5.97, \text { median }=16 \\
\text { range }=5-59, n=162\end{array}$ & $\begin{array}{l}\text { Mean }=11.38 \pm 3.88, \text { median }=11 \\
\text { range }=5-38, n=243\end{array}$ & ${ }^{*} t=10.63, \mathrm{df}=250.9, P<0.001$ \\
\hline $\begin{array}{l}\text { Brood cell length }(\mathrm{mm}) \\
\quad \text { (females) }\end{array}$ & $\begin{array}{l}\text { Mean }=20.25 \pm 5.68, \text { median }=18.5 \\
\text { range }=13-35, n=16\end{array}$ & $\begin{array}{l}\text { Mean }=14.11 \pm 7.81, \text { median }=12, \\
\text { range }=8-50, n=54\end{array}$ & ${ }^{*} \mathrm{t}=3.45, \mathrm{df}=33.50, P=0.0015$ \\
\hline $\begin{array}{l}\text { Brood cell length }(\mathrm{mm}) \\
\quad \text { (males) }\end{array}$ & $\begin{array}{l}\text { Mean }=17.62 \pm 6.95, \text { median }=17 \\
\text { range }=6-59, n=58\end{array}$ & $\begin{array}{l}\text { Mean }=13.15 \pm 5.45, \text { median }=12, \\
\text { range }=6-23, n=26\end{array}$ & ${ }^{*} \mathrm{t}=3.17, \mathrm{df}=60.64, P=0.002$ \\
\hline $\begin{array}{l}\text { Brood cell volume }\left(\mathrm{mm}^{3}\right) \\
\quad \text { (general) }\end{array}$ & $\begin{array}{l}\text { Mean }=481 \pm 168, \text { median }=452 \\
\text { range }=141-1667, n=162\end{array}$ & $\begin{array}{l}\text { Mean }=893 \pm 303, \text { median }=863 \\
\text { range }=392-2983, n=243\end{array}$ & $t=-17.44, \mathrm{df}=392, \mathrm{P}<0.0001$ \\
\hline $\begin{array}{l}\text { Brood cell volume }\left(\mathrm{mm}^{3}\right) \\
\quad(\text { females })\end{array}$ & $\begin{array}{l}\text { Mean }=572 \pm 155, \text { median }=522, \\
\text { range }=367-989, n=16\end{array}$ & $\begin{array}{l}\text { Mean }=1107 \pm 607, \text { median }=942 \\
\text { range }=628-3925, n=54\end{array}$ & $t=-5.78, \mathrm{df}=68, \mathrm{P}<0.0001$ \\
\hline $\begin{array}{l}\text { Brood cell volume }\left(\mathrm{mm}^{3}\right) \\
\quad \text { (males) }\end{array}$ & $\begin{array}{l}\text { Mean }=497 \pm 194, \text { median }=480 \\
\text { range }=169-1667, n=58\end{array}$ & $\begin{array}{l}\text { Mean }=1032 \pm 419, \text { median }=942 \\
\text { range }=471-1805, n=26\end{array}$ & ${ }^{*} \mathrm{t}=-6.08, \mathrm{df}=30, \mathrm{P}<0.0001$ \\
\hline Vestibular cell length (mm) & $\begin{array}{l}\text { Mean }=20.35 \pm 9.32, \text { median }=19.5 \\
\text { range }=4-39, n=14\end{array}$ & $\begin{array}{l}\text { Mean }=22.68 \pm 10.00, \text { median }=20 \\
\text { range }=11-50, n=19\end{array}$ & $t=-0.67, \mathrm{df}=31, P=0.50$ \\
\hline Intercalary cell (mm) & $\begin{array}{l}\text { Mean }=2.5 \pm 0.94, \text { median }=2.5 \\
\text { range }=1-4, n=14\end{array}$ & $\begin{array}{l}\text { Mean }=3.15 \pm 0.74, \text { median }=3 \\
\text { range }=2-4, n=20\end{array}$ & $t=-2.24, \mathrm{df}=32, P=0.032$ \\
\hline Cell partition (mm) & $\begin{array}{l}\text { Mean }=1.21 \pm 0.36, \text { median }=1 \\
\text { range }=1-2, n=24\end{array}$ & $\begin{array}{l}\text { Mean }=1.29 \pm 0.65, \text { median }=1 \\
\text { range }=1-4, n=25\end{array}$ & $U=311.5, P=0.79$ \\
\hline Closing plug (mm) & $\begin{array}{l}\text { Mean }=3 \pm 1.08, \text { median }=3 \\
\text { range }=1-5, n=13\end{array}$ & $\begin{array}{l}\text { Mean }=3.47 \pm 2.41, \text { median }=3 \\
\text { range }=1-10, n=19\end{array}$ & ${ }^{*} t=-0.75, \mathrm{df}=26.66, P=0.45$ \\
\hline $\begin{array}{l}\% \text { of nests including the } \\
\text { vestibular cell }\end{array}$ & $58.3 \%, n=24$ & $44 \%, n=25$ & $G=0.48, P=0.51$ \\
\hline $\begin{array}{l}\text { Number of brood cells } \\
\text { per nest }\end{array}$ & $\begin{array}{l}\text { Mean }=3.33 \pm 1.20, \text { median }=3 \\
\text { range }=1-6, n=24\end{array}$ & $\begin{array}{l}\text { Mean }=4.66 \pm 1.20, \text { median }=5 \\
\text { range }=3-7, n=25\end{array}$ & $\mathrm{U}=\mathbf{1 3 6}, \mathrm{P}<\mathbf{0 . 0 0 1}$ \\
\hline $\begin{array}{l}\text { Number of intercalary } \\
\text { cells per nest }\end{array}$ & $\begin{array}{l}0.45 \pm 0.77, \text { median }=0 \\
\text { range }=0-2, n=24\end{array}$ & $\begin{array}{l}\text { Mean }=0.92 \pm 0.90, \text { median }=1 \\
\text { range }=0-3, n=25\end{array}$ & $U=211, P=0.055$ \\
\hline Sex-ratio per nest & $\begin{array}{l}\text { Mean }=0.71 \pm 0.41, \text { median }=1 \\
\text { range }=0-1, n=24\end{array}$ & $\begin{array}{l}\text { Mean }=0.30 \pm 0.38, \text { median }=0 \\
\text { range }=0-1, n=25\end{array}$ & $U=451, P=0.001$ \\
\hline$\%$ of nests with sex-ratio $=0$ & $20.8 \%, n=24$ & $56 \%, n=25$ & $G=5.04, P=0.03$ \\
\hline$\%$ of nests with sex-ratio $=1$ & $62.5 \%, n=24$ & $16 \%, n=25$ & $G=9.43, P=0.002$ \\
\hline Mortality per nest (\%) & $\begin{array}{l}\text { Mean }=0.43 \pm 0.34, \text { median }=0.5 \\
\text { range }=0-1, n=24\end{array}$ & $\begin{array}{l}\text { Mean }=0.57 \pm 0.30, \text { median }=0.5 \\
\text { range }=0-1, n=25\end{array}$ & $U=236, P=0.20$ \\
\hline
\end{tabular}


throughout the winter. Between late April and May 2004, they were then opened carefully by sawing along the longitudinal side.

For each nest, the following data were recorded: (1) number of brood cells, (2) number of intercalary cells, (3) length of brood cells, (4) length of intercalary cells, (5) length of vestibular cell, (6) thickness of mud partitions, and (7) thickness of closing plug. All measurements were taken with a digital caliper to the nearest $0.02 \mathrm{~mm}$. We also calculated the brood cell volume approximating cells as cylinders (volume $=\pi^{*}$ (nest diameter $\left./ 2\right)^{2 *}$ cell length).

Contents of the cells were collected and preserved in $70 \%$ ethanol for determination of species and sex and for measurement of the head width of the adult individuals (with a digital calliper to the nearest $0.02 \mathrm{~mm}$ ). With these data, we obtained: (1) the nest mortality, defined as the number of dead brood cells (number of brood cells including parasites, dry prey or wasp remains) divided by the total number of brood cells, and (2) sex-ratio, defined as: [number of males/(number of males + females)]. The brood cells were differentiated from the intercalary cells by their length and contents. If a cell was shorter than the minimum value recorded for brood cells and it did not include any sign of prey or wasp remains, it was considered as an intercalary cell [1].

Because not all the used nests were found to be completed (i.e. having a closing plug) at the moment of removal from field, the pool of data used differed depending on the analysis. Number of brood cells, number of intercalary cells, length of the vestibular cell, thickness of the closing plug, sex-ratio and mortality were assessed only for completed nests ( $n=24$ for 6 -mm nest and 25 for $10-\mathrm{mm}$ nests), while length of brood cells and intercalary cells and thickness of mud partitions entered in some analyses including also non-completed nests (e.g. head width vs. brood cell length) ( $n=14-162$ for $6-\mathrm{mm}$ nests and $19-243$ for $10-\mathrm{mm}$ nests, depending on the sample, e.g. individuals emerged or cells measured). Thus, the sample size changes with some analyses due to the fact that: (1) we used only completed nests for some calculations (as explained above), (2) the number of males and females emerged from the nests were different between the two kinds of nests, (3) the vestibular cell (VC) was not present in all the analysed nests, (4) the intercalary cells (IC) were not present in all nests. In addition, $17 \mathrm{CP}$ were accidentally destroyed while opening the nest and could not be measured. The sample size is specified for each analysis in the Table 1 .

\subsection{Statistical analysis}

Nest parameters and wasp head widths were normally distributed (one-sample Kolgomorov-Smirnov, $P>0.05$ for all variables), so we used parametric statistics. Means of lengths, thicknesses and head widths were compared with the parametric unpaired Student's $t$-test in case of homogeneity of variance (F-test with $P>0.05$ ); otherwise, the Aspin-Welch test was used. The number of brood cells, sex-ratio and mortality were not normally distributed, not even after natural log-transformation (one-sample Kolgomorov-Smirnov, $P<0.05$ for all variables), so we used non- parametric statistics while analysing these data. Medians of brood cells number and of intercalary cells number and mortality per nest were compared with non-parametric Mann-Whitney test. The likelihood-ratio G-test was used to compare proportions. Pearson correlation test was used to look for linear associations.

General linear models (linear regressions [one-way ANOVA] or ANCOVA, depending on the presence of qualitative explanatory variables) were performed to look for significant effects of independent variables on the dependent variables: number of brood cells, brood cell length, offspring size, sex-ratio and mortality. Logistic regressions were performed to look for significant effects of independent variables on the binary responses: (1) dead cell/alive cell, or (2) male cell/female cell. In text and tables, mean values are reported with their standard deviations.

All the statistics were performed with XLSTAT 2008 (Addinsoft, New York, USA).

\section{Results}

Out of 196 trap-nests, 158 were used by solitary wasps. From these nests emerged species of Ancistrocerus, Allodynerus, Symmorphus, Euodynerus (Eumeninae), Psenulus and Trypoxylon (Crabronidae) (Polidori et al. unpublished data). One hundred and ten nests were used by $E$. (P.) posticus, 54 of $6 \mathrm{~mm}$ and 56 of $10 \mathrm{~mm}$ in diameter. Out of these, 49 (24 of $6 \mathrm{~mm}$ and 25 of $10 \mathrm{~mm}$ in diameter) presented a closing plug at the entrance (i.e. they were complete nests) at the moment of collecting them from field. Nests which presented a closing plug during the field checks still had it in September, so that we assumed that wasps had one generation in the study year.

\subsection{Nest structure and productivity}

Nests were invariably composed of a series of linear brood cells divided by mud partitions (convex internally and concave externally), while intercalary cells and vestibular cell were either present or absent. Thirty-four complete nests had at least one IC, while 33 had a VC. On the whole, 23 complete nests had all the described structures present (Fig. 1).

Brood cells were, on average, shorter in $10-\mathrm{mm}$ nests both on the whole $(11.38 \pm 3.88 \mathrm{~mm}$ vs. $17.03 \pm 5.97 \mathrm{~mm})$ (Fig. 2a) and considering separately brood cells from which emerged males and females (Table 1). However, mean brood cell volume was larger in 10 -mm nests $\left(893 \pm 303 \mathrm{~mm}^{3}\right.$ vs. $481 \pm 168 \mathrm{~mm}^{3}$ ) (Table 1 and Fig. 2b). This is accompanied by the fact that $6-\mathrm{mm}$ nests contained fewer brood cells $($ median $=3$ ) than $10-$ mm nests ( median $=5$ ) (Table 1$)$. When different nest variables are included in a single general linear model ( $n=49$ nests) $\left(R^{2}=0.59, \mathrm{df}=42\right.$; ANCOVA: $F=10.03$, $\mathrm{df}=6, P<0.0001)$, the number of $\mathrm{BC}$ changed significantly with nest diameter $(F=24.28, P<0.0001$; more $B C$ in $10-\mathrm{mm}$ nests) (Fig. 3), while it decreased significantly with $B C$ length $(F=13.25, P=0.001)$ and marginally with the number of IC $(F=4.71, P=0.036)$; the presence of the VC had also a negative effect on the number of $\mathrm{BC}(F=17.94, P<0.001)$. Mean $\mathrm{BC}$ volume $(F=0.02, P=0.89)$ and mean MP thickness 

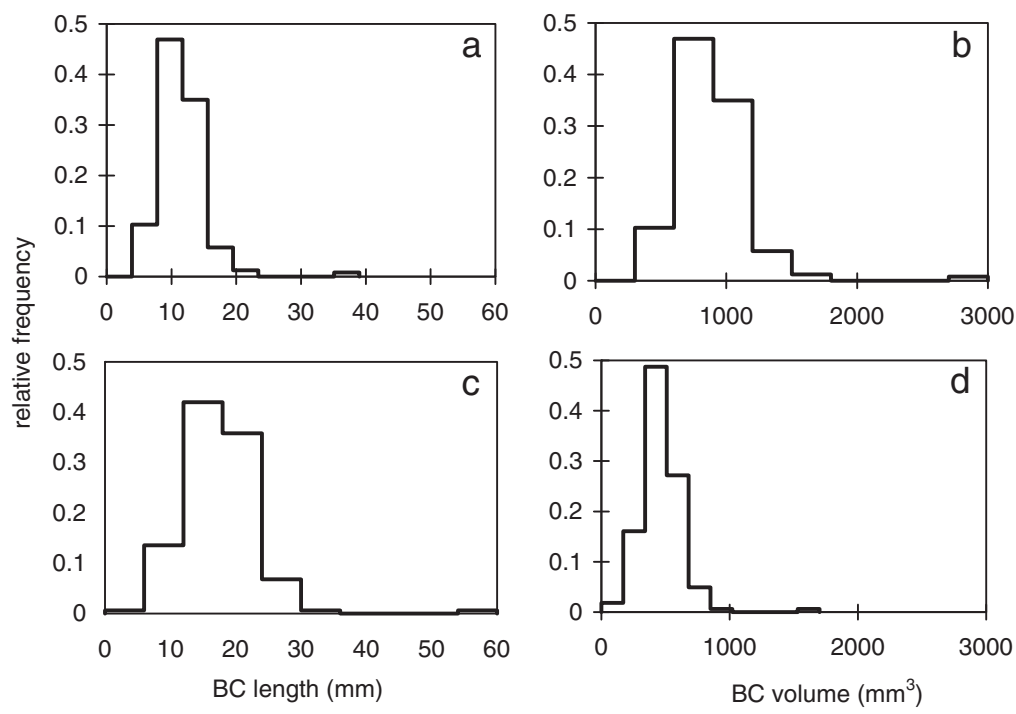

Fig. 2. Relative frequency distribution of brood cell lengths (a, c) and brood cell volumes (b, d) in 10-mm diameter (a, b) and 6-mm diameter (c, d) nests of E. (P.) posticus.

$(F=0.001, P=0.98)$ had no effect on the number of BC. Using a subset of data (23 nests) to allow the inclusion of further variables (CP thickness, VC length, mean IC length) in a new model $\left(R^{2}=0.75, \mathrm{df}=14 ;\right.$ ANOVA: $\left.F=5.38, \mathrm{df}=8, P=0.003\right)$, no additional factors significantly affected the number of brood cells; moreover, the number of intercalary cells lost significance.

The length of intercalary cells was greater in $10-\mathrm{mm}$ nests ( $3.15 \pm 0.74 \mathrm{~mm}$ vs. $2.5 \pm 0.94 \mathrm{~mm}$ ), but no differences appeared in the length of the vestibular cell $(6-\mathrm{mm}$ nests: $20.35 \pm 9.32 \mathrm{~mm}, 10$-mm nests: $22.68 \pm 10.00 \mathrm{~mm}$ ) (Table 1). Also, vestibular cells were not more often constructed in $10-\mathrm{mm}$ nests, and the number of intercalary cells did not change with the type of nest (Table 1 ). Cell partitions and closing plug were not thicker in 10-mm nests (MP: 6-mm nests: $1.21 \pm 0.36 \mathrm{~mm}, 10$-mm nests: $1.29 \pm 0.65 \mathrm{~mm}$; CP: 6 -

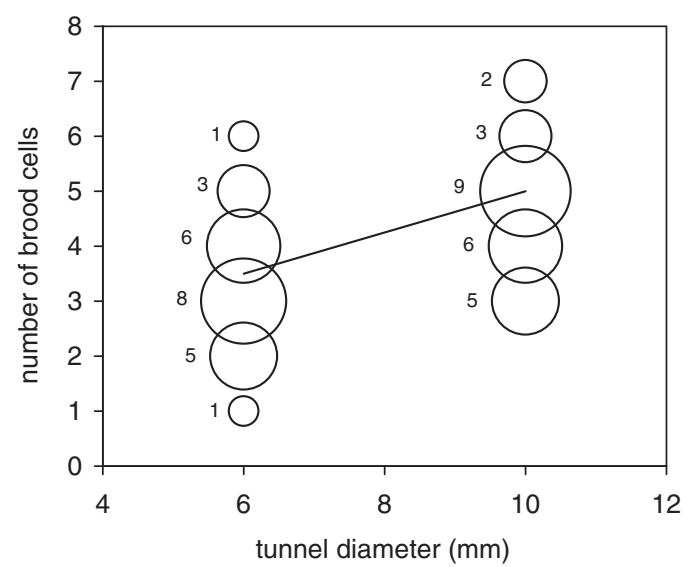

Fig. 3. Relationship between tunnel diameter and number of brood cells in the nests of $E$. (P.) posticus. Size of circles relates to the number of observations for any given ( $\mathrm{x}, \mathrm{y})$ point (shown on the left of circles). $\mathrm{mm}$ nests: $3 \pm 1.08 \mathrm{~mm}, 10$ - $\mathrm{mm}$ nests: $3.47 \pm 2.41 \mathrm{~mm}$ ) (Table 1).

Finally, brood cell length did not increase or decrease with its position inside the nest $\left(R^{2}=0.019, \mathrm{df}=203\right.$, $P=0.052$ ), although the mud partitions (closing plug not included since it was always the thickest mud wall) get thicker as they get closer to the entrance $\left(R^{2}=0.036\right.$, $\mathrm{df}=203, P=0.006$ ), although the low value of $\mathrm{R}^{2}$ shows that only a small part of the variance is explained by the linear model.

\subsection{Body size of adult offspring}

Euodynerus (P.) posticus is sexually dimorphic: males were smaller than females in both the 6 - $\mathrm{mm}$ nests (head width: $2.51 \pm 0.24 \mathrm{~mm}$ vs. $3.14 \pm 0.21 \mathrm{~mm}$; Student's $t$-test: $t=-10.40, \mathrm{df}=85, P<0.0001)$ and in the $10-\mathrm{mm}$ nests $(2.68 \pm 0.26 \mathrm{~mm}$ vs. $3.22 \pm 0.16 \mathrm{~mm}$; Student's $t$-test: $t=-12.15, \mathrm{df}=62, P<0.0001)$.

Individuals (males + females) which emerged from 6$\mathrm{mm}$ nests were smaller than those which emerged from $10-\mathrm{mm}$ nests (Table 1 ); however, the variation in male size is the responsible for such overall difference, because female size did not differ between the two types of nests (Table 1 ). Head width varies primarily with the sex of the individuals $\left(R^{2}=0.65, \mathrm{df}=66\right.$; ANCOVA: $F=10.50, \mathrm{df}=10$, $P<0.0001 ; F=40.12, P<0.0001$ ) (smaller head width for males). BC length ( $F=0.081, P=0.77)$, BC volume $(F=0.094$, $P=0.76)$, nest diameter $(F=0.58, P=0.45)$ and position of the $\mathrm{BC}$ in the nest $(F=0.12, P=0.99)$ did not have any effect on head width. Removing the sex variable from the model, however, a positive effect of nest diameter on head width appeared $(F=30.22, P<0.0001)$, while the other factors were still non-significant (BC length: $F=2.35, P=0.13$; $\mathrm{BC}$ volume: $F=0.22, P=0.63$; position of the $\mathrm{BC}$ in the nest: $F=0.24, P=0.95$ ). In addition, head width (males + females) correlated positively with BC volume (Pearson 

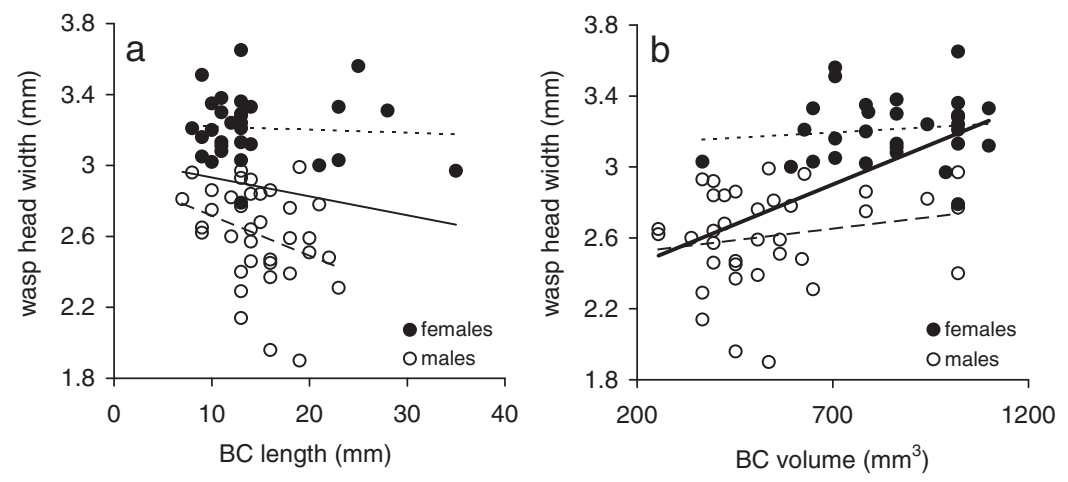

Fig. 4. Relationships between brood cell length (a) and brood cell volume (b), wasp sex, and wasp head width in $E$. ( $P$.) posticus nests. Short-dashed trend lines refer to females, long-dashed trend lines refer to males, and continuous trend lines refer to all wasps. Bold trend line for all wasps in (b) refers to the only significant linear correlation.

correlation test: $r=0.58, n=66, P<0.0001$ ) (Fig. 4a) but it did not correlate with $\mathrm{BC}$ length (Fig. 4b) (Pearson correlation test: $r=-0.14, n=66, P=0.25)$. These correlations no longer are significant when considering the two sexes separately (males, BC length: $r=-0.33, n=36$, $P=0.05$; males, $\mathrm{BC}$ volume: $r=0.20, \quad n=36, P=0.24$; females, $\mathrm{BC}$ length: $r=-0.06, n=30, P=0.75$; females, $\mathrm{BC}$ volume: $r=0.12, n=30, P=0.54$ ) (Fig. 4a,b).

Finally, when considering separately the two sexes, one notes that both female and male size did not change from innermost to outermost brood cells (females: $R^{2}=0.010$, $\mathrm{df}=28 ; P=0.6$; males: $\left.R^{2}=0.017, \mathrm{df}=34 ; P=0.43\right)$.

\subsection{Sex-ratio of offspring}

Sex-ratio was significantly male-biased in 6-mm nests (median $=1, \chi^{2}=17.6, \mathrm{df}=1, P<0.0001$ ) and significantly female-biased in $10-\mathrm{mm}$ nests (median $=0, \chi^{2}=16.0$, $\mathrm{df}=1, P<0.0001$ ) (Table 1 ). Moreover, a significantly higher proportion of nests with sex-ratio of 0 (all females) was found in 10-mm nests, while nests with sex-ratio of 1 (all males) were more often found in $6-\mathrm{mm}$ nests (Table 1 ). A binary logistic regression $\left(R^{2}=0.45, \mathrm{df}=62\right.$; Wald $=15.37, \mathrm{df}=4, P=0.003$ ) showed that the probability for a brood cell to include a male or a female wasp depends on different variables. Females were more likely to emerge from $10-\mathrm{mm}$ nests $\left(\chi^{2}=5.74, P=0.017\right)$ (Fig. 5a), from longer $\left(\chi^{2}=5.10, P=0.024\right)$ and larger $\left(\chi^{2}=18.78\right.$, $P<0.0001$ ) brood cells (Fig. 5b), and marginally from innermost cells $\left(\chi^{2}=3.98, P=0.046\right)$. The situation was obviously opposite for associations with male emergences.

\subsection{Offspring mortality}

Mortality was caused by moulding/fungi or other unknown factors. In fact, the only parasitoid found, Pseudoxenus sp. (Strepsiptera), which generally does not kill the host, was clearly visible while protruding from two females of two 10-mm diameter nests.

Mortality per nest was not higher in $10-\mathrm{mm}$ nests or in 6 - $\mathrm{mm}$ nests $($ median $=0.5$ for both kinds of nest) (Table 1 ), and the probability of a brood cell to be a cell where the individual died did not fit with a binary logistic regression considering as explanatory variables the nest diameter, brood cell length, brood cell volume, cell partition thickness and cell position $\left(R^{2}=0.03, \mathrm{df}=204\right.$; Wald $=7.72$, $\mathrm{df}=5, P=0.075)$. Also, mortality per nest did not fit with a general linear model considering as explanatory variables the nest diameter, brood cell length, brood cell volume, number of brood cells, cell partition thickness, and number of intercalary cells $\left(R^{2}=0.24, \mathrm{df}=42\right.$; ANCOVA: $F=2.38$, $\mathrm{df}=6, P=0.06$ ).

Mortality did not differ between nests including a vestibular cell and those without a vestibular cell (Mann-
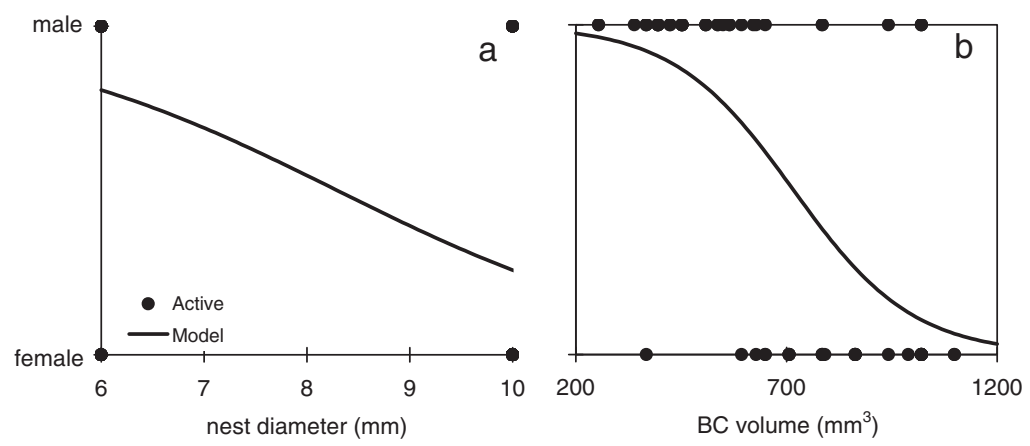

Fig. 5. Effect of tunnel diameter (a) and brood cell volume (b) on the probability to obtain a male or a female from the nests of $E$. (P.) posticus, following binary logistic models. 
Whitney test: $U=303, n_{1}=32, n_{2}=17, P=0.52$ ), but a marginal negative correlation was found between mortality per nest and length of the vestibular cell (Pearson correlation test: $r=-0.42, n=23, P=0.047$ ).

\section{Discussion}

The availability and size of the holes used by woodnesting wasps and bees vary in time and space in the complex environment where they live $[8,10,49]$. Here we showed that the use of small or large nests affects wasp allocation behaviour and fitness. We will discuss below our results in relation to what has been observed in other species of solitary bees and wasps.

\subsection{The "small nest syndrome" I: reduced productivity}

Brood cells in the nests of $E$. (P.) posticus were shorter in $10-\mathrm{mm}$ nests both on the whole and considering separately brood cells from which emerged males and females. This seems to be a widespread pattern in the genus Euodynerus. For example, the data reported on seven out of eight species of this genus by Krombein [1] show the same pattern that we observed in the nests of $E$. (P.) posticus (Table 2), although for some species the trend can only be suggested given the small sample size. For Eudoynerus megaera (Lepeletier), more recent observations [50] confirm the Krombein's limited data. Such inverse relationship between nest diameter and cell length was found also in many other vespid and apoid wasps $[33,50,51]$. Despite such cell length-nest diameter relationship, cell volume is found to be larger in widerdiameter nests [51]. Thus, also for E. (P.) posticus, it is possible to reject the assumption that a wasp female simply closes a brood cell after filling it with an appropriate amount of provision. In fact, such an assumption implies that the volume of a cell is more or less constant due to the species- and sex-specific amount of provision in the cell, and thus little affected by the nest diameter; on the contrary, cell volume positively correlated with the diameter of the nesting cavity [51]. Cowan [24], who studied the allocation patterns of Euodynerus foraminatus (Saussure) through weighing the brood provisions rather than measuring cell size, reported that prey weight per nest increased with nest diameter, and that greater amounts of food produced larger individuals. Given our results on the relationship between brood cells volume and nest diameter and between this and offspring size, we suggest that also $E$. (P.) posticus may allocate more food in larger nests.

The positive effect of tunnel length on the number of brood cells, found in E. (P.) posticus, seems to be widespread in trap-nesting Hymenoptera $[1,14,16,52]$ (although in the bee Osmia cornuta Latreille the number of brood cells seem to be maximized in medium-length nests [ $8 \mathrm{~mm}$ vs. 7 and $9 \mathrm{~mm}$ ] [53]). This pattern evidently

Table 2

Data from Krombein [1] showing mean values for a number of nest variables observed in eight species of Euodynerus.

\begin{tabular}{|c|c|c|c|c|c|c|c|c|c|}
\hline \multirow[b]{2}{*}{ Species } & \multicolumn{3}{|c|}{$\begin{array}{l}\text { Number of brood (BC) and } \\
\text { intercalary (IC) cells }\end{array}$} & \multicolumn{3}{|c|}{$\begin{array}{l}\text { Female BC length }(L, \mathrm{~mm}) \text { and } \\
\text { volume }\left(V, \mathrm{~mm}^{3}\right)\end{array}$} & \multicolumn{3}{|c|}{$\begin{array}{l}\text { Male BC length }(L, \mathrm{~mm}) \text { and } \\
\text { volume }\left(V, \mathrm{~mm}^{3}\right)\end{array}$} \\
\hline & $4.8 \mathrm{~mm}$ & $6.4 \mathrm{~mm}$ & $12.7 \mathrm{~mm}$ & $4.8 \mathrm{~mm}$ & $6.4 \mathrm{~mm}$ & $12.7 \mathrm{~mm}$ & $4.8 \mathrm{~mm}$ & $6.4 \mathrm{~mm}$ & $12.7 \mathrm{~mm}$ \\
\hline E. foraminatus foraminatus (Saussure) & $\begin{array}{l}\text { BC: } 5.4 \\
\text { IC: } 1.7 \\
n=10\end{array}$ & $\begin{array}{l}\text { BC: } 5.5 \\
\text { IC: } 2.3 \\
n=11\end{array}$ & - & $\begin{array}{l}L: 22 \\
V: 398 \\
n=10\end{array}$ & $\begin{array}{l}L: 20 \\
V: 643.2 \\
n=24\end{array}$ & - & $\begin{array}{l}L: 16 \\
V: 289.5 \\
n=52\end{array}$ & $\begin{array}{l}L: 13 \\
V: 418.1 \\
n=29\end{array}$ & - \\
\hline E. foraminatus apopkensis (Robertson) & $\begin{array}{l}\text { BC: } 8.1 \\
\text { IC: }- \\
n=97\end{array}$ & $\begin{array}{l}\text { BC: } 7.6 \\
\text { IC: }- \\
n=104\end{array}$ & - & $\begin{array}{l}L: 20.3 \\
V: 367.2 \\
n=53\end{array}$ & $\begin{array}{l}L: 17.5 \\
V: 562.8 \\
n=418\end{array}$ & - & $\begin{array}{l}L: 15.3 \\
V: 276.8 \\
n=772\end{array}$ & $\begin{array}{l}L: 13.4 \\
V: 431 \\
n=308\end{array}$ & - \\
\hline E. megaera (Lepeletier) & $\begin{array}{l}\text { BC: } 4.1 \\
\text { IC: } 0.2 \\
n=9\end{array}$ & $\begin{array}{l}\text { BC: } 6.3 \\
\text { IC: } 0.5 \\
n=24\end{array}$ & $\begin{array}{l}\text { BC: } 9.4 \\
\text { IC: } 0 \\
n=5\end{array}$ & $\begin{array}{l}L: 34 \\
V: 615.1 \\
n=3\end{array}$ & $\begin{array}{l}L: 23 \\
V: 739.7 \\
n=103\end{array}$ & $\begin{array}{l}L: 13 \\
V: 1646.4 \\
n=38\end{array}$ & $\begin{array}{l}L: 25 \\
V: 452.3 \\
n=38\end{array}$ & $\begin{array}{l}L: 17 \\
V: 546.7 \\
n=51\end{array}$ & $\begin{array}{l}L: 10 \\
V: 1266.5 \\
n=7\end{array}$ \\
\hline E. schwarzi (Krombein) & $\begin{array}{l}\text { BC: } 5 \\
\text { IC: } 0 \\
n=3\end{array}$ & $\begin{array}{l}\text { BC: } 5 \\
\text { IC: } 2 \\
n=5\end{array}$ & $\begin{array}{l}\text { BC: } 6.5 \\
\text { IC: } 0 \\
n=2\end{array}$ & $\begin{array}{l}L: 23 \\
V: 416.1 \\
n=4\end{array}$ & $\begin{array}{l}L: 28 \\
V: 900.5 \\
n=23\end{array}$ & $\begin{array}{l}L: 14 \\
V: 1773.1 \\
n=11\end{array}$ & $\begin{array}{l}L: 18 \\
V: 325.6 \\
n=10\end{array}$ & $\begin{array}{l}L: 17 \\
V: 546.7 \\
n=17\end{array}$ & - \\
\hline E. hidalgo boreoorientalis (Bequaert) & $\begin{array}{l}\text { BC: } 5 \\
\text { IC: } 1 \\
n=3\end{array}$ & $\begin{array}{l}\text { BC: } 8 \\
\text { IC: } 0.5 \\
n=4\end{array}$ & - & $\begin{array}{l}L: 18 \\
V: 325.6 \\
n=11\end{array}$ & $\begin{array}{l}L: 16 \\
V: 514.6 \\
n=9\end{array}$ & - & $\begin{array}{l}L: 21 \\
V: 379.9 \\
n=4\end{array}$ & $\begin{array}{l}L: 13 \\
V: 418.1 \\
n=15\end{array}$ & - \\
\hline E. pratensis pratensis (Saussure) & - & $\begin{array}{l}\text { BC: } 4.4 \\
\text { IC: } 1.6 \\
n=5\end{array}$ & $\begin{array}{l}\text { BC: } 4.5 \\
\text { IC: } 3.0 \\
n=2\end{array}$ & - & $\begin{array}{l}L: 22 \\
V: 707.6 \\
n=6\end{array}$ & $\begin{array}{l}L: 16 \\
V: 2026.4 \\
n=2\end{array}$ & - & $\begin{array}{l}L: 21 \\
V: 675.4 \\
n=6\end{array}$ & $\begin{array}{l}L: 11 \\
V: 1393.2 \\
n=5\end{array}$ \\
\hline E. guerrero (Saussure) & $\begin{array}{l}\text { BC: } 3 \\
\text { IC: } 2 \\
n=1\end{array}$ & $\begin{array}{l}\text { BC: } 4 \\
\text { IC: } 2 \\
n=6\end{array}$ & - & - & $\begin{array}{l}L: 26 \\
V: 836.2 \\
n=9\end{array}$ & - & $\begin{array}{l}L: 31 \\
V: 560.8 \\
n=2\end{array}$ & $\begin{array}{l}L: 20 \\
V: 643.2 \\
n=10\end{array}$ & - \\
\hline E. molestus molestus (Saussure) & $\begin{array}{l}\text { BC: } 3 \\
\text { IC: } 0 \\
n=2\end{array}$ & $\begin{array}{l}\text { BC: } 5 \\
\text { IC: } 0 \\
n=5\end{array}$ & - & $\begin{array}{l}L: 34 \\
V: 615.1 \\
n=2\end{array}$ & $\begin{array}{l}L: 25 \\
V: 804 \\
n=22\end{array}$ & - & $\begin{array}{l}L: 31 \\
V: 560.8 \\
n=6\end{array}$ & $\begin{array}{l}L: 17 \\
V: 546.7 \\
n=7\end{array}$ & - \\
\hline
\end{tabular}

BC volumes were calculated by using the provided BC length and nest diameter data, approximating the cells to cylinders (calculations come from mean lengths so that volumes are not followed by sample size). Nests analysed had one of three-hole diameter: $4.8 \mathrm{~mm}, 6.4 \mathrm{~mm}, 12.7 \mathrm{~mm}$. 
causes a reduction in offspring productivity for females using small nests, and considering that in E. (P.) posticus mortality did not change between large and small nests, this also means a reduction in fitness for such females. A reduction of number of brood cells in smaller nests was found in few other Euodynerus species (in E. megaera [1], in the E. foraminatus population studied by Cowan [24], and maybe, as suggested by few data, in two other species (Table 2)). In contrast, the number of intercalary cells did not increase with nest diameter in $E$. (P.) posticus and probably, with the possible exclusion of Euodynerus foraminatus foraminatus (Saussure), in any other studied species of the genus (Table 2). Perhaps, such kind of cells not provisioned and apparently not affecting the rate of parasitism - were not preferred by the wasps in case of a large nesting space, which would be preferentially filled with additional brood cells.

Our findings contrast with those predicted by the hypothesis of Smith and Fretwell [20], which postulated that parents should attempt to adjust offspring number rather than size to maximize fitness per unit invested. That is, parents should invest no more than that required to obtain the highest fitness reward per unit investment even if a given offspring does not secure the maximal fitness possible. This hypothesis is not supported by our data on $E$. (P.) posticus, which seems to prefer to invest in both less and smaller (males) or similar-size (females) offspring in smaller nests (see below).

\subsection{The "small nest syndrome" II: reduced body size}

Differences in body size can be observed among individuals of the same sex, as a consequence of the allocation, by nesting females, of different provisioning strategies [42,54-56].

Despite brood cell length being greater in small nests of E. (P.) posticus, brood cell volume was still higher in large nests. This result is similar to those found in other species of Euodynerus (at least in those with reliable sample size, and suggested for most of the others, Table 2). Wasps probably faced a reduction of space building longer cells, and this seemed to secure enough cell volume to maintain the offspring size equal in females. This last result is of particular interest, because it could mean that nesting females tried to invest more in females (proportionally to males) in small nests. In Hymenoptera, females are the most expensive individuals to produce: they are generally larger than males and need to be fed with a greater amount of food [24,57-60]; in addition, their size greatly affects their future fitness, given that size limits the foraging distance and the amount of food that can be carried to the nest, during a period of parental care in which males have little, if none, role $[26,27,61,62]$.

Cowan [24] found that females of E. foraminatus fed with more food were larger, produced more offspring, and lived longer than those fed with lower prey mass. Moreover, the food amount being equal, a female will be larger than a male (i.e. females gain more weight per unit of food than males).

Thus, females of $E$. (P.) posticus may adaptively raise proportionally larger females, relative to males, in smaller nests to minimize the risk associated with a reduction of their size. As far as we know this is the first report of a possibly adaptive behaviour favouring greater female size in poorer nesting conditions. On the other side, from a mother's point of view, investing in large males would be adaptive if they perform some activity of brood care whose performance depends on size. For example, in two species of the genus Trypoxylon there were no significant differences between the weights among males emerging from different diameter trap-nests, while differences were observed among females, which were smaller if emerging from smaller trap-nests [15,63]. Unlike most solitary aculeates, males of some Trypoxylon spp. usually guard the nest while it is being provisioned by the female, chasing away ants and parasitoids [54,64]. Thus, Trypoxylon females may invest proportionally more in males in small nests to secure their success as guards. Despite this comparison should be taken with caution, because in many Trypoxylon males are often produced in the first cells provisioned [1], a similar situation was also found for the bee Megachile apicalis Spinola, which lay fertilized eggs (females) first. In this case, adult daughters produced under low resource level were smaller, but there was no significant difference for adult sons [65]. On the contrary, male territoriality, a behaviour which has no evident advantage for female fitness, would not promote higher investment in male size. For example, in E. foraminatus size of both sexes increased with nest diameter [24]. In this species, larger males establish territories in proximity of the nest entrance and mate more often than non-territorial males. For a female, to mate with a resident or a nonresident male does not affect fitness; for example it does not affect offspring size because this depends on provision mass and not on the genetic contribution of the father [24].

\subsection{The "small nest syndrome" III: investment in the cheaper sex}

Trivers and Willard [66] suggested that individual females could be selected according to their reproductive condition to bias the sex-ratio of their own offspring. A 1:1 equilibrium sex-ratio is expected only when sons and daughters cost the same to produce [66], which, however, is not the general case in Hymenoptera (see above). Both Boomsma [67] and Helms [68] showed that in hymenopterans a biased population-level sex allocation occurs if individuals adjust the sex-ratio of their offspring in response to resource availability (male-biased ratio when resources are scarce) $[57,69,70]$. For example, in the solitary bee Osmia rufa (L.), during the nesting period, the sex-ratio of progeny shifted from a female bias toward a male bias, and the shift was correlated with the declining provisioning efficiency of female bees [57]. Experimentally reduced food availability produces the same effect in the honeybee-hunting wasp Philanthus triangulum Fabricius [21] and in the bee $M$. apicalis [65].

Thus, if the offered nesting cavities are larger or smaller than those usually available in nature, a bias towards a greater production of one of the sexes could arise, as long as there is sexual dimorphism as regards size [66], as occurs in E. (P.) posticus. 
Our results support this hypothesis. In fact, in $E$. (P.) posticus the sex-ratio was male-biased in small nests and female-biased in large nests. A similar effect of tunnel diameter on sex-ratio was found in other cavity-nesting wasps [1,71], including few other Euodynerus spp. [1,24], although absence of relationships are known [72,73].

An opposite situation from what we found was observed at least in one megachilid bee (Megachile pugnata Say), in which the proportion of females increased with decreasing the tunnel length of the trap-nests [74], but this trend does not seem widespread in wood-nesting aculeates.

We also found that females of E. (P.) positicus are more likely to allocate a male offspring in the outermost cells and female offspring in the innermost cells. This mechanism was already reported in other cavity-nesting wasps and bees, including other species of Euodynerus [1,24,71,75-77]; but see exceptions in some Trypoxylon spp.: $[1,14,64,78]$, and it is believed to represent an adaptation to proterandry (males emerging before females in the season) or, alternatively, a response to the behaviour of the parasitoids, which invading the nests entrance and attacking the outermost cells would kill most probably the cheaper sex (males) (Pérez-Maluf, quoted in [14]).

\subsection{Mortality: nest size does not matter}

Nest mortality in trap-nesting wasps and bees was observed to extremely vary among species and among generations of a single species, and to be due to insect parasitoids and other causes, such as fungal infestation and/or mould $[1,12]$. In our study, parasitoids had probably no impact on the observed population: strepsipterans of the genus Pseudoxenos were found in two individuals, but these organisms normally do not kill the host [1]; such parasites were recorded in association with few other species of Euodynerus [1]. In contrast, cuckoo wasps of the genus Chrysis were often reared from Euodynerus nests (seven out of eight species in [1]) but were not found in this study. Instead, much of the mortality was due to fungi or unknown factor, and this kind of mortality seemed to be not related to nest characteristics, including nest diameter, cells number and morphology, and mud partitions.

In other species the size of the trap-nests seems to explain an important proportion of the mortality variance. In Trypoxylon lactitarse Saussure, mortality rates, at least in some years, were higher in smaller nests [30]. Also in Trypoxylon agamennon Richards and in the bee Megachile (Chrysosarus) pseudanthidioides Moure the mortality was higher in small nests [14,31].

It has been proposed that vestibular cell might have arisen as an adaptation to reduce the access of natural enemies into the nest $[64,78,79]$. However, studies do not support this hypothesis, when considering mortality due to parasitoids [32,34,35]. However, Asís et al. [33] and Seidelmann [32] did see a reduction in the mortality rate due to failed egg eclosion and fungi attack in early stages in the nests with a vestibular cell, which suggests the role of these structures as a buffer. This contrasts only partially with our result. In fact, if on one hand the presence of a vestibular cell had no effect on mortality, a marginally negative correlation was found between mortality per nest and length of the vestibular cell. In addition, we found that the length of intercalary cells was greater in 10-mm nests, although this could be just a product of the general longer tunnel available to nest in this kind of traps.

Another factor commonly associated with risk of mortality is the position of the brood cell in the nest, although a general pattern is not visible. For example, in the bee Centris (Hemisiella) tarsata Smith and in the wasp T. attenuatum the innermost cells were the most attacked by parasitoids $[33,80]$, but in the bee 0 . rufa and in the wasp Trypoxylon beaumonti Antropov the risk of cell parasitism decreased from near the nest entrance to the bottom of the nest $[57,75]$. Concerning mortality due to causes different from parasitoidism, this was significantly lower in the innermost cells of T. attenuatum nests [33]. In contrast, although the recorded trend for $E$. (P.) posticus was only close to significance, it seems that for this species mortality decreases towards outermost cells. More data are necessary to confirm this possibility.

\section{Conclusions}

E. (P.) posticus has an evident adaptive nesting behaviour. In fact, females: (1) built shorter brood cells in wider nesting cavities, (2) produced smaller males, but not smaller females, in smaller nests, (3) produced more males in smaller nests. All these findings are consistent with an optimization of the available nesting space, and possibly this optimization helps nesting females to maximize their fitness in small nests, which, however, is still reduced. On the other side, using both small and large nests would maintain the overall sex-ratio weakly unbalanced, given the nest size-dependent sex-ratio. In addition, mortality seems to weakly depend on nest parameters, so that probably small nests have not an additional higher risk that may negatively affect fitness, relative to large nests. Nevertheless, the patterns found for $E$. (P.) posticus, when compared to what observed in other species, confirm how variable could be the adaptations of such insects to the environmental conditions where they live.

\section{Conflict of interest statement}

No conflicts of interest affect the authors.

\section{Acknowledgement}

Thanks are due to Simone Bigatti for help during the field and laboratory work. The Ticino Regional Park provided the permits for the placements of trap-nests in the field. We thank R. Dallai for the identification of strepsipteran parasites. We are indebted to an anonymous referee, which gave many useful suggestions and comments on the manuscript, improving it.

\section{References}

[1] K.V. Krombein, Trap-nesting wasps and bees: life histories, nests, and associates, Smithsonian press, Washington DC, 1967.

[2] J.A. Collins, D.T. Jennings, A simplified holder for eumenid nesting blocks (Hymenoptera: Eumenidae), Entomol. News 95 (1984) 58-62. 
[3] A. Gathmann, H.J. Greiler, T. Tscharntke, Trap-nesting bees and wasps colonizing set-aside fields: succession and body size, management by cutting and sowing, Oecologia 98 (1994) 8-14.

[4] I Steffan-Dewenter, Landscape context affects trap-nesting bees, wasps, and their natural enemies, Ecol. Entomol. 27 (2002) 631-637.

[5] R.D. Loyola, R.P. Martins, Habitat structure components are effective predictors of trap-nesting Hymenoptera diversity, Basic. App. Ecol. 9 (2008) 735-742.

[6] H. Taki, B.F. Viana, P.G. Kevan, F.O. Silva, M. Buck, Does forest loss affect the communities of trap-nesting wasps (Hymenoptera: Aculeata) in forests? Landscape vs. local habitat conditions, J. Insect Conserv. 12 (2008) 15-21.

[7] I. Steffan-Dewenter, K. Leschke, Effects of habitat management on vegetation and above-ground nesting bees and wasps of orchard meadows in Central Europe, Biodiversity and Conservation 12 (2003) 19531968.

[8] E.F. Morato, R.P. Martins, An overview of proximate factors affecting the nesting behavior of solitary wasps and bees (Hymenoptera: Aculeata) in preexisting cavities in wood, Neotrop. Entomol. 35 (2006) 285-298.

[9] H.V. Danks, Nest mortality factors in stem-nesting aculeate Hymenoptera, J. Animal Ecol. 40 (1971) 63-77.

[10] H.V. Danks, Populations and nesting-sites of some aculeate Hymenoptera nesting in Rubus, J. Animal Ecol. 40 (1971) 79-82.

[11] S. Stearns, The evolution of life histories, Oxford University Press, Oxford, 1992.

[12] K.M. O’Neill, Solitary wasps: natural history and behavior, Comstock Publishing Associates, Ithaca and London, 2001.

[13] M.L.T. Buschini, Life-history and sex allocation in Trypoxylon (syn, Trypargilum) lactitarse (Hymenoptera; Crabronidae), J. Zool. Syst. Evol. Res. 45 (2007) 206-213.

[14] M.L.T. Buschini, S. Fajardo, Biology of the solitary wasp Trypoxylon (Trypargilum) agamemnon Richards 1934 (Hymenoptera: Crabronidae) in trap-nests, Acta Zoologica 91 (2010) 429-432, doi:10.1111/j.14636395.2009.00429.x

[15] R.E. Coville, C. Griswold, Nesting biology of Trypoxylon xanthandrum in Costa Rica with observations on its spider prey (Hymenoptera: Sphecidae: Araneae: Senoculidae), J. Kansas Entomol. Soc. 56 (1983) 205216

[16] M.L.T. Buschini, F. Niesing, L.L. Wolff, Nesting biology of Trypoxylon (Trypargilum) lactitarse Saussure (Hymenoptera: Crabronidae) in trapnests in Southern Brazil, Brazilian J. Biol. 66 (2006) 907-917.

[17] R.W. Longair, Sex-ratio variations in Xylophilous Aculeate Hymenoptera, Evolution 35 (1981) 597-600.

[18] K.M. O’Neill, A.M. Pearce, R.P. O'Neill, R.S. Miller, Offspring size and sexratio variation in a feral population of alfalfa leafcutting bees (Hymenoptera: Megachilidae), Ann. Entomol. Soc. Am. 103 (2010) 775-784.

[19] V.J. Tepedino, P.F. Torchio, The influence of nest-hole selection on sexratio and progeny size in Osmia lignaria propinqua (Hymenoptera: Megachilidae), Ann. Entomol. Soc. Am. 82 (1989) 355-360.

[20] C.C. Smith, S.D. Fretwell, The optimal balance between size and number of offspring, Am. Nat. 108 (1974) 499-506.

[21] E Strohm, K.E. Linsenmair, Low resource availability causes extremely male-biased investment ratios in the European beewolf, Philanthus triangulum F. (Hymenoptera, Sphecidae), Proc. R. Soc. Lond. B 264 (1997) 423-429.

[22] J.-Y. Kim, R.W. Thorp, Maternal investment and size-number trade-off in a bee, Megachile apicalis, in seasonal environments, Oecologia 126 (2001) 451-456

[23] J. Bosch, Production of undersized offspring in a solitary bee, Animal Behav. 75 (2008) 809-816.

[24] D.P. Cowan, Parental investment in two solitary wasps Ancistrocerus adiabatus and Euodynerus foraminatus (Eumenidae: Hymenoptera), Behav. Ecol. Sociobiol. 9 (1981) 95-102.

[25] J.Y. Kim, Female size and fitness in the leaf-cutter bee Megachile apicalis, Ecol. Entomol. 22 (1997) 275-282.

[26] J.R. Coelho, L.D. LaDage, Foraging capacity of the great golden digger wasp, Sphex ichneumoneus L., Ecol. Entomol. 24 (1999) 480-483.

[27] C. Polidori, P. Mendiola, J.D. Asís, J. Tormos, M.D. Garcia, J. Selfa, Predatory habits of the grasshopper-hunting wasp Stizus continuus (Hymenoptera: Crabronidae): diet preference, predator-prey size relationships and foraging capacity, J. Nat. Hist. 43 (2009) 2985-3000.

[28] J.D. Asís, J. Tormos, S.F. Gayubo, Territorial dynamics and contest behaviour in the solitary wasp Stizus continuus (Hymenoptera: Apoidea: Crabronidae), Behaviour 143 (2006) 83-104.

[29] C. Polidori, F. Andrietti, Nest abandonment in the solitary wasp Cerceris arenaria (Hymenoptera: Crabronidae): escape, leave open or destroy the door? Sociobiology 47 (2006) 455-470.

[30] M.L.T Buschini, Life-history, sex allocation in Trypoxylon (syn. Trypargilum) lactitarse (Hymenoptera; Crabronidae), J. Zool. Syst. Evol. Res. 45 (2007) 206-213.
[31] A. Zillikens, J. Steiner, Nest architecture, life cycle and cleptoparasite of the neotropical leaf-cutting bee Megachile (Chrysosarus) pseudanthidioides Moure (Hymenoptera: Megachilidae), J, Kansas Entomol. Soc. 77 (2004) 193-202.

[32] K. Seidelmann, The function of the vestibulum in nests of a solitary stem-nesting bee, Osmia rufa (L.), Apidologie 30 (1999) 19-29.

[33] J.D. Asís, A. Benéitez, J. Tormos, S.F. Gayubo, M.A.M. Tomé, The Significance of the vestibular cell in trap-nesting wasps (Hymenoptera: Crabronidae): does its presence reduce mortality? J. Insect. Behav. 20 (2007) 289-305

[34] M.V.B. García, J. Adis, Comportamento de nidificação de Trypoxylon (Trypargilum) rogenhoferi Kohl (Hymenoptera, Sphecidae) em una floresta inundável de várzea na Amazônia Central, Amazoniana 18 (1995) 259-282.

[35] A.J.S. Weaving, A comparison of nesting success and nesting habits in some Afrotropical aculeate wasps, with particular reference to nest parasites (Hymenoptera: Sphecidae, Eumenidae), Ann. Cape Prov. Mus. Nat. Hist. 19 (1995) 181-224.

[36] J.M. Carpenter, J.M. Cumming, A character analysis of the North American potter wasps (Hymenoptera: Vespidae; Eumeninae), J. Nat. Hist. 19 (1985) 877-916.

[37] K.M. Guichard, Greek wasps of the family Eumenidae (Hymenoptera) with a key to the European genera, Entomol. Gaz. 31 (1980) 39-59.

[38] M.J. West-Eberhard, Observations of Xenorhynchium nitidulum (Fabricius) (Hymenoptera, Eumeninae), a primitively social wasp, Psyche 94 (1987) 317-323.

[39] M.J West-Eberhard, The behavior of the primitively social wasp Montezumia cortesioides Willink (Vespidae, Eumeninae) and the origins of vespid sociality, Ecol. Ethol. Evol. 17 (2005) 51-65.

[40] R.W. Matthews, J.R. Matthews, Nesting behavior of Abispa ephippium (Fabricius) (Hymenoptera: Vespidae: Eumeninae): extended parental care in an Australian mason wasp, Psyche (2009) Article ID 851694, 15 pages.

[41] K. Iwata, Evolution of instinct: comparative ethology of Hymenoptera, Amerind Publishing Co, New Delhi, 1976.

[42] D.P. Cowan, The solitary and presocial Vespidae, in : K.G. Ross, R.W. Matthews (Eds.), The social biology of wasps, Cornell University Press, Ithaca, NY, 1991, pp. 33-37.

[43] F. Sanza, L. Castro, S.F. Gayubo, Sobre las especies ibero-baleares de Euodynerus (Euodynerus) Dalla Torre 1904 (Hymenoptera: Vespidae: Eumeninae), Bol. SEA 33 (2003) 59-64.

[44] H.E. Evans, Observations on the nests and prey of eumenid wasps (Hymenoptera, Eumenidae), Psyche 84 (1977) 255-259.

[45] J.A. Collins, D.T. Jennings, Spruce budworm and other lepidopterous prey of Eumenid wasps (Hymenoptera: Eumenidae) in spruce-fir forests of Maine, Great Lakes Entomol 20 (1987) 127-133.

[46] T. Itino, Differential diet breadths and species coexistence in leafrollerhunting eumenid wasps, Res. Pop. Ecol. 34 (1992) 203-211.

[47] P. Cerretti, S. Hardersen, F. Mason, G. Nardi, M. Tisato, M. Zapparoli (Eds.), Conservazione Habitat Invertebrati, 3, Cierre Grafica Editore, Verona, 2004

[48] F. Sanza, Revision de los eumenidos de la Peninsula Iberica (Hymenoptera: Eumenidae), PhD thesis, Universidad de Salamanca, Salamanca, Spain, 1997.

[49] A. Budrienè, E. Budrys, Ž. Nevronytè, Solitary Hymenoptera Aculeata inhabiting trap-nests in Lithuania: nesting cavity choice and niche overlap, Latvijas Entomologs 41 (2004) 19-31.

[50] D.A. Jenkins, R.W. Matthews, Cavity-nesting Hymenoptera in disturbed Habitats of Georgia and South Carolina: nest architecture and seasonal occurrence, J. Kansas Entomol. Soc. 77 (2004) 203-214.

[51] E. Budrys, A. Budrienè, Ž. Nevronytè, Dependence of brood cell length on nesting cavity width in xylicolous solitary wasps of genera Ancistrocerus and Symmorphus (Hymenoptera: Vespidae), Acta Zool. Lituanica 20 (2010) 68-76.

[52] C.M.L. Aguiar, A.G. Garófalo, Nesting biology of Centris (Hemisiella) tarsata Smith (Hymenoptera, Apidae, Centridini), Rev. Bras. Zool. 21 (2004) 477-486.

[53] J. Bosch, The nesting behaviour of the mason bee Osmia cornuta (Latr) with special reference to its pollinating potential (Hymenoptera, Megachilidae), Apidologie 25 (1994) 84-93.

[54] H.J. Brockmann, A. Grafen, Mate conflict and male behaviour in a solitary wasp, Trypoxylon (Trypargilum) politum (Hymenoptera: Sphecidae), Anim. Behav. 37 (1989) 232-255.

[55] A. Molumby, Why make daughters larger? Maternal sex-allocation and sex-dependent selection for body size in a mass-provisioning wasp, Trypoxylon politum, Behav. Ecol. 8 (1997) 279-287.

[56] R.C. Peruquetti, M.A. Del Lama, Alocação sexual e seleção sexo-dependente para tamanho de corpo em Trypoxylon rogenhoferi Kohl (Hymenoptera, Sphecidae), Rev. Brasil. Entomol. 47 (2003) 581-588. 
[57] K. Seidelmann, Open-cell parasitism shapes maternal investment patterns in the Red Mason bee Osmia rufa, Behav. Ecol. 17 (2006) 839-848.

[58] K.M. O'Neill, R.P. O'Neill, Sex allocation, nest structure, and prey of Isodontia mexicana (Saussure) (Hymenoptera: Sphecidae), J. Kansas Entomol. Soc. 76 (2003) 447-454.

[59] E. Strohm, K.E. Linsenmair, Measurement of parental investment and sex allocation in the European beewolf Philanthus triangulum F. (Hymenoptera: Sphecidae), Behav. Ecol. Sociobiol. 47 (1999) 76-88.

[60] M.S. Santoni, M.A. Del Lama, Nesting biology of the trap-nesting Neotropical wasp Trypoxylon (Trypargilum) aurifrons Shuckard (Hymenoptera, Crabronidae), Rev. Brasil. Entomol. 51 (2007) 369-376.

[61] E.D. Araujo, M. Costa, J. Chaud-Netto, H.G. Fowler, Body size and flight distance in stingless bees (Hymenoptera: Meliponini): inference of flight range and possible ecological implications, Braz. J. Biol. 64 (2004) 563-568.

[62] A. Zurbuchen, L. Landert, J. Klaiber, A. Müller, S. Hein, S. Dorn, Maximum foraging distances in solitary bees: only few individuals have the capability to cover long foraging distances, Biol. Conserv. 143 (2010) 669-676.

[63] J. Brockmann, Male behavior, courtship and nesting in Trypoxylon (Trypargilum) monteverdeae (Hymenoptera: Sphecidae), J. Kansas Entomol. Soc. 65 (1992) 66-84.

[64] R.E. Coville, P.L. Coville, Nesting biology and male behavior of Trypargilum tecnoctitlan in Costa Rica (Hymenoptera: Sphecidae), Ann. Entomol. Soc. Am. 73 (1980) 110-119.

[65] J.Y. Kim, Influence of resource level on maternal investment in a leafcutter bee (Hymenoptera: Megachilidae), Behav. Ecol. 10 (1999) 552556.

[66] R.L. Trivers, D.E. Willard, Natural selection of parental ability to vary the sex-ratio of offspring, Science 179 (1973) 90-92.

[67] J.J. Boomsma, Sex-investment ratios in ants: has female bias been systematically overestimated? Am. Nat. 133 (1989) 517-532.

[68] K.R. Helms, Sexual size dimorphism and sex-ratios in bees and wasps, Am. Nat. 143 (1994) 418-434.
[69] S.A. Frank, Sex allocation in solitary bees and wasps, Am. Nat. 146 (1995) 316-323.

[70] E.L. Charnov, The theory of sex allocation, Princeton University Press, Princeton, NJ, 1982.

[71] V.J. Tepedino, F.D. Parker, Nest selection, mortality and sex-ratio in Hoplitis fulgida (Cresson) (Hymenoptera: Megachilidae), J. Kansas Entomol. Soc. 57 (1984) 181-189.

[72] S. Oku, T. Nishida, Factors affecting female-biased Sex-ratio in trapnesting wasp, Trypoxylon malaisei, Res. Pop. Ecol. 41 (1999) 169-175.

[73] K.M. O'Neill, J.F. O'Neill, Prey, nest associates, and sex-ratios of Isodontia mexicana (Saussure) (Hymenoptera: Sphecidae) from two sites in New York State, Entomol. Americana 115 (2009) 90-94.

[74] V.J. Tepedino, D.R. Frohlich, Mortality factors, pollen utilization, and sex-ratio in Megachile pugnata Say (Hymenoptera: Megachilidae), a candidate for commercial sunflower pollination, J. Kansas Entomol. Soc. 90 (1982) 269-274.

[75] J. Tormos, J.D. Asís, S.F. Gayubo, J. Calvo, M.A.M. Tomè, Ecology of crabronid wasps found in trap-nests from Spain (Hymenoptera: Spheciformes), Fla. Entomol. 88 (2005) 278-284.

[76] J.M.F. Assis, E. Camillo, Diversidade, sazonalidade e aspectos biologicos de vespas solitarias (Hymenoptera: Sphecidae, Vespidae) em ninhos armadilhas na Região de Ituiutaba, MG, An. Soc. Entomol. Bras. 26 (1997) 335-347.

[77] D.B. Jayasingh, C.A. Taffe, The biology of the eumenid mud-wasp Pachodynerus nasidens in trapnests, Ecol. Entomol. 7 (1982) 283-289.

[78] R.E. Coville, Wasps of the genus Trypoxylon subgenus Trypargilum in North America (Hymenoptera: Sphecidae), University of California Press, Berkeley, 1982.

[79] R.E. Coville, C. Griswold, Biology of Trypoxylon (Trypargilum) superbum (Hymenoptera: Sphecidae), a spider-hunting wasp with extended guarding on the brood by males, J. Kansas Entomol. Soc. 57 (1984) 365-376.

[80] M.L.T. Buschini, L.L. Wolff, Nesting biology of Centris (Hemisiella) tarsata Smith in Southern Brazil (Hymenoptera, Apidae, Centridini), Brazilian J. Biol. 66 (2006) 1091-1101. 